\title{
Organizational forms and technical efficiency of the dairy processing industry in Southern Brazil
}

\author{
Caetano Luiz Beber ${ }^{1 *}$ (D), Sebastian Lakner ${ }^{1,2}$ and loannis Skevas ${ }^{3}$
}

\author{
* Correspondence: cbeber@gwdg. \\ de \\ ${ }^{1}$ Department of Agricultural \\ Economics and Rural Development, \\ Georg-August-University Göttingen, \\ Platz der Göttinger Sieben 5, 37073 \\ Gottingen, Germany \\ Full list of author information is \\ available at the end of the article
}

\begin{abstract}
The objective of this article is to assess the determinants of the technical efficiency of dairy processing firms in Southern Brazil while accounting for their different organizational forms, namely cooperatives and investor-owned firms. The data from 243 milk processors in southern Brazil, including firm structure, management capacity, and organizational choice of dairies, were analyzed. A production frontier is specified to estimate technical efficiency and identify its potential driving sources. Bayesian techniques are used to estimate the model. An average efficiency of $77 \%$ indicates that the actual output is $23 \%$ below its potential, which implies that output could, on average, be increased by approximately $31.6 \%$, under ceteris paribus conditions. Economies of scale were also detected. The analysis reveals that the management capacity within companies is the main determinant of efficiency. Idle capacities of processing plants are an important source of inefficiencies and cooperatives are more efficient than investor-owned firms, despite their transaction costs potentially being higher and the five vaguely defined property rights inherent to the traditional cooperatives which they must overcome. Knowledge about the cooperatives' objectives other than profit maximization would provide a more realistic comparison against investor-owned firms. This study assessed the determinants of the efficiency levels of dairy processing companies in an emerging economy using a unique own dataset with data collected at a plant level. Based on the results, manifold managerial and political implications have been derived that can benefit the dairy industry of developing and emerging economies.
\end{abstract}

Keywords: Dairy processing firms, Technical efficiency, Brazilian dairy sector, Dairy cooperatives

\section{Springer Open}

\section{Introduction}

The dairy industry is a key agribusiness sector for rural value creation and important for food security in remote rural areas. In Brazil, the dairy industry corresponds to $5.8 \%$ of the total value share in national agricultural GDP and $15 \%$ of animal production (IBGE 2017). It also generates around 4.7 million jobs. In 2017, 1.17 million farms produced 33.5 billion liters of milk, making it the fourth largest producer in the world.

(c) The Author(s). 2021 Open Access This article is licensed under a Creative Commons Attribution 4.0 International License, which permits use, sharing, adaptation, distribution and reproduction in any medium or format, as long as you give appropriate credit to the original author(s) and the source, provide a link to the Creative Commons licence, and indicate if changes were made. The images or other third party material in this article are included in the article's Creative Commons licence, unless indicated otherwise in a credit line to the material. If material is not included in the article's Creative Commons licence and your intended use is not permitted by statutory regulation or exceeds the permitted use, you will need to obtain permission directly from the copyright holder. To view a copy of this licence, visit http://creativecommons.org/licenses/by/4.0/. 
Since the early 1990 s to the present, Brazilian dairy processing has been consolidating and undergoing a process of rapid restructuring and multi-nationalization.

The rise of supermarkets and the deregulation of the dairy market that occurred in the early 1990s freed retail and farm prices, which brought a sharp increase in firm's competition on price and cost cutting. This has led to the entrance of large multinational processors in the sector (Carvalho 2008; Chaddad and Jank 2006). National companies were slow to respond to this path of consolidation, mainly for political and management problems (Beber et al. 2018). Cooperatives and investor-owned firms (IOFs) adopted different strategies to adapt to this new context. However, the shutdown of dairy enterprises was inevitable, taking thousands of farmers along, causing irreparable damages to family farms.

Sustaining the participation of these dairies with solid technological and economic performances, although challenging, is crucial for farmers and rural communities, even more so in developing and emerging economies (Nguyen et al. 2018). This is especially true in the case of cooperatives, which might pursue other objectives besides that of pure profit maximization (Franken and Cook 2013; Soboh et al. 2012). In several cases, the cooperatives' objectives are, e.g., to maximize members' benefits. They might also provide important social functions in rural areas as, e.g., collecting milk from remote farming locations (Magalhães 2007) or offering inputs at lower costs or feed and veterinary services. These actions considerably improve farmers' profits and incomes (Chagwiza et al. 2016; Gupta and Roy 2012). While it is relatively easy for cooperatives to enter modern agri-food chains, it is challenging to sustain their participation by following the market requirements, especially for the traditional cooperatives (Berdegué 2001). This context shows evidences of low competitiveness of the processing companies, especially the cooperatives. In southern Brazil, such cooperatives also face a mix of difficult challenges: to reorganize the supply chain in their coverage area, to collect milk over long distances, to transfer technological and managerial improvements for farmers, and to have qualified human resources (Beber et al. 2019, 2018). Measuring companies' efficiency levels and identify their determinants might offer important information for policy makers and managers to promote the resilience of production systems and rural communities.

Based on this background, the main research-question here is which is the right legal set-up for dairy supply processing companies in developing and emerging economies? This paper aims to investigate and display the efficiency and productivity differences of such a typical institutional set-up in a way which reflects the different organizational forms, namely cooperatives vs IOFs. Therefore, this study adds to the firm-organization literature by defining the production frontier and estimating the technical efficiency (TE) levels of dairy processing companies. In summary, the literature is controversial in what concerns the efficiency of cooperatives and our study contributes with further insights into these debates.

Therefore, in this study, we assess a set of determinants that, according to the literature, may have a significant impact on the (in)efficiency of dairy processing companies. First, we included "cooperatives" as a determinant of efficiency. Among the few empirical studies comparing the TE of dairy cooperatives and IOFs, we found different results showing that both cooperatives and IOFs can be more efficient depending on the context, the data used, and the objective of the performance measured. Beckmann 
(2000) suggests that dairy cooperatives perform less efficiently than IOFs due to their institutional form and their social functions in rural areas. Furesi et al. (2013) also showed a higher efficiency in favor of IOFs, but found no technological differences between sheep dairy processing cooperatives and IOFs and Sardinia, Italy. The studies of Porter and Scully (1987) and Ferrier and Porter (1991) corroborate, showing IOFs to be more efficient. Hirsch et al. (2020), in an analysis of the European dairy industry, also reveal that cooperatives are less efficient than IOFs and less flexible, possibly led by the different objectives of cooperatives (maximizing members' profits). In this study, besides company age, the processing plant idleness was one of the main drivers of efficiency. Chaddad (2007a) showed that cooperatives usually add value only in the initial stages of the industrial process. Furthermore, and with few exceptions, agricultural cooperatives in developing countries are generally not well prepared to develop a competitive and efficient commercialization model (Ruiz-Guerra and Molina-Moreno 2014). This fact leads to an increased dependency on other companies to market the farmers' production. Scarce capital for investments, and their organizational characteristics in general, usually slows down the development of such projects (Cook 1995). The organizational structure of the traditional cooperatives ${ }^{1}$ has inherently "five vaguely defined property rights" (Cook 1995) that impact negatively on their organization and performance (Grashuis 2018). Furthermore, part of the literature also argues that internal transaction costs might decrease the efficiency of cooperatives. It may occur because their objectives and decision-making structures are not exclusively focused on profits and returns on assets, but rather on the interests of the members (Beckmann 2000; Hirsch and Hartmann 2014).

Other authors suggest that cooperatives may be more efficient by having a more conservative financial structure. They argue that this can be important for dealing with crisis and changes of policies and for paying higher prices to farmers (Soboh et al. 2014) from one side. Form the other side, it may alleviate market imperfections and reduce transaction costs for farmers, for example (von Braun et al. 1989). Other factors making cooperatives succeed are also the homogeneity of member's interests and low costs of ownership. This holds even in the absence of serious market imperfections that would make market contracting costly for the producers (Hansmann 1996). Singh et al. (2001) assessing processing plants in India also found cooperatives to be more efficient. The same outcome was found by Soboh et al. (2014) comparing the efficiency of European dairy processing firms. They found cooperatives to be slightly less efficient but having a more productive technology. Finally, Soboh et al. (2012) also used data from European dairy processing firms to show that cooperatives could either outperform their IOF counterparts or be outperformed by them, depending on the approach used to account for the cooperatives' differential objectives. Studies using approaches other than stochastic frontier analysis (SFA) also found cooperatives to be at least as economically efficient as other potential forms of organization such as IOFs (Boyle 2004; Soboh et al. 2011). Soboh et al. (2011) also suggest that marketing cooperatives in the Irish dairy

${ }^{1}$ The Brazilian Federal Law 5764 of 1971 still does not allow for large variations on the traditional cooperatives' ownership and governance structures. Although it allows for a proportionality of shares and votes, this mechanism is rarely found among the cooperatives in the country, and especially in the southern region, where most of the cooperatives are formed by small-scale farmers. See Beber et al. (2018); Chaddad (2007b) and (2007a) for further details. 
sector behave "as if" they were profit maximizing companies regarding the prices paid for the farmers' milk.

Following other empirical studies, we assume in our study that the cooperatives' objective is to maximize a company's profits, and we want to investigate which organizational form shows higher levels of efficiency based on the measured output. A composite measure of the cooperative performance including other objectives ${ }^{2}$ the cooperative might have, such as maximizing the members' welfare, would rather offer a more precise indicator of their overall performance (Franken and Cook 2013) and should be considered in further studies.

In our set of determinants of (in)efficiencies, we also included the type of inspection service adopted by the companies. With this, our intention is to verify whether the level of sanitary restrictions and the commercialization area have any impact on the efficiency levels. Just as with the sanitary aspects, the quality aspects of the milk processed by the dairies are also included. We use an indirect approach, controlling for the companies that have a program of payment based on quality premiums/penalties (and not just quantity). Finally, we also investigate the effects of the idle capacities on (in)efficiency.

This paper contributes to the literature in three ways-first, we investigate TE in an intermediate step in the agri-food supply chain, while the vast majority of the literature focuses on farm-level analysis. Despite the importance of the milk processing industry for agribusiness in general, the literature investigating the TE of dairies is limited. Furthermore, among the few empirical studies comparing the TE of dairy cooperatives and IOFs, only a few of them have assessed the determinants of efficiency levels, such as that of Hirsch et al. (2020). Second, we use a unique own dataset of 243 companies with data collected at plant level. The few studies assessing TE at the same processing level use general data from national statistics databases where little or no information on management practices is available. Third, while most of the available studies on TE in the processing stage refer to developed countries-where data is more easily accessed-we conducted this analysis in an emerging economy. Data is often not available in developing and emerging countries because of the high participation share of the informal activities (Wilkinson and Rocha 2006), especially in the dairy sector (Revoredo-Giha and Renwick 2016) and the high costs of data collection.

This study uses data from Paraná, southern Brazil, one of the most promising and dynamic dairy production areas in the world ${ }^{3}$. The socioeconomic and structural characteristics of this area make it an interesting case study for the assessment of attributes with potential to promote the agro-industrialization in developing and emerging economies. Consequently, the results contribute for the rural development of several countries in South America, North, South and South-East Asia, Western Europe, and Africa, where the dairy sector has an important participation on the agricultural income.

\footnotetext{
${ }^{2}$ For further discussion about this topic, Soboh et al. (2009) provide a general overview on the different performance measures according to the different objectives of the cooperatives, which range from profit maximization to members' welfare maximization and all possible combinations in between. However, they also highlight the complexity of comparing companies with such heterogeneity, thus arguing that: "The largest part of the existing work on Agricultural Marketing cooperatives assumes a single, well-defined objective." This is done for simplification throughout economic modelling and the objective of IOFs is the simplest.

${ }^{3}$ The southern region includes the states of Paraná, Santa Catarina, and Rio Grande do Sul.
} 
The article is organized as follows: in the next sections, we present the study area with context of dairy processing companies in Brazil and how we propose to measure the efficiency of processing companies. The methodological framework employed and the Bayesian techniques used to estimate the model are shown in sequence, followed by a description of the data. Next, the principal results and the discussion are then presented. The article ends with some concluding remarks and policy implications.

\section{Study area}

Southern Brazil is today the largest dairy producing zone in the country and the state of Paraná is the third largest dairy state in Brazil, producing 4.7 billion liters, or 13\% (8.9\% in 2006) of the national production. This volume was produced by around 87,000 farmers, according to the last agricultural census in the country (IBGE 2018). In comparison to the previous censuses, it has observed a constant growth trend in the state. From 2006 to 2017, there has been an increase of 78\% in production, and 71\% from 1996 to 2006. Internally, the state also shows large differences in farm sizes and technology adoption among its regions (IPARDES 2010).

Regarding the processing segment of the chain, in 2017 there were 3809 companies involved in collecting, processing, reprocessing, and commercializing milk in the country. These companies employed 135,552 workers, of whom 10,798 (8.0\%) in the 295 companies of Paraná (see supplementary material for a detailed description of the dairy processing segment in Brazil). The dairy industry has grown considerably in the past years in the whole country, pushed by the increased consumption of dairy products by the rising middle-class consumers in Brazil. From 2007 to 2017, the Gross Value of Industrial Production (GVIP) of the dairy processing industry has grown by $161.8 \%$ in Brazil and $143.6 \%$ in Paraná.

It has also observed a higher share of products with higher added value in 2017 when compared to 2009 (Fig. 1). The participation of fluid milk decreased by -10 percentage points and powder milk by -2.7 , while cheeses $(+6.8)$ and dairy drinks and yogurts $(+2.2)$ increased.

However, these processing companies are not performing well in international markets. While the trade Brazilian balance of the whole agriculture and agro-food industries was positive at US\$ 60 billion FOB in 2016, the same figure for dairy products

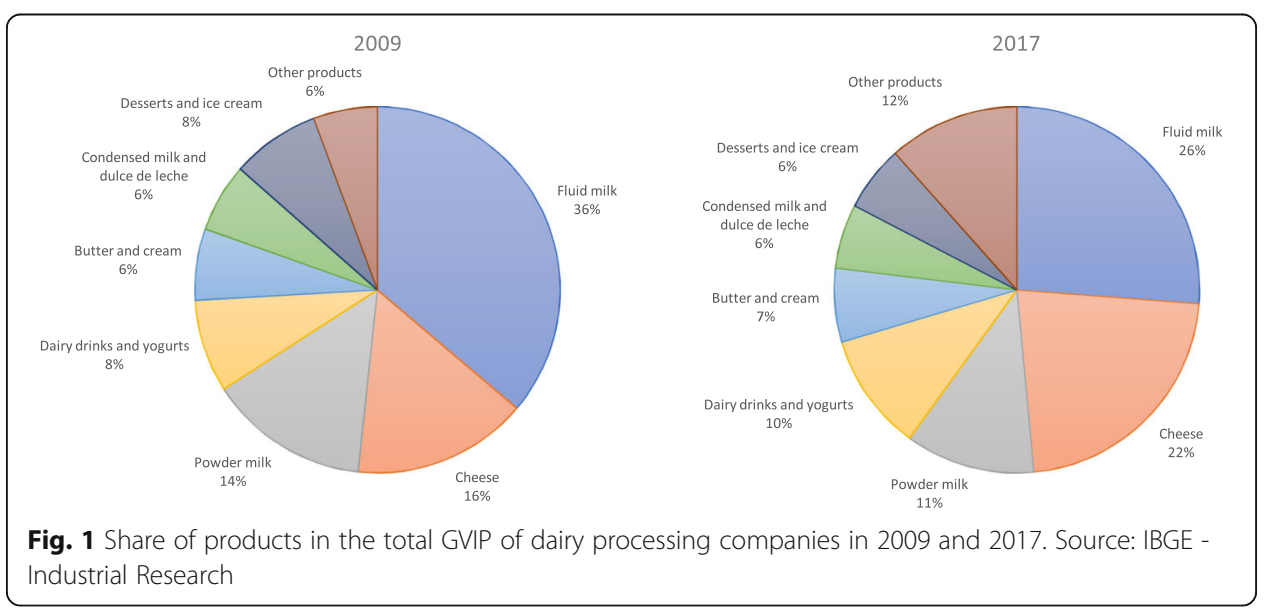


with higher added value such as cheese, yogurt, and derivates summed up to US\$ 141 million FOB, ${ }^{4}$ (OECD and FAO 2015; IBGE 2017). The dairy exports from Brazil account for less than $1 \%$ of the total world exports (FAOSTAT 2019), representing a low market share in the international market. This represents the low competitiveness and development of the dairy processing segment in the country.

Another important aspect influencing the commercialization of dairy products in Brazil is the inspection service for animal products. It is separated into Federal (SIF), State (SIE), and Municipal (SIM) inspectorates, ${ }^{5}$ which only allow commercialization within the scope of their territories. The SIF has more sanitary and quality restrictions and also allows exports; the SIM has the least, allowing only commercialization at the level of municipalities. In general, companies adopting the SIM are small companies because its adoption is cheaper. Companies are allowed to move between such labels. The Ministry of Agriculture, Livestock and Supply (MAPA) in Brazil intends to consolidate the national sanitary inspection systems and create the Brazilian System of Animal Products Inspection (SISBI-POA). This consolidation would have the effect of levelling sanitary parameters in accordance to the current SIF.

In general, most of the transactions between processing companies and producers are done on the spot and the milk is paid based on volumes. However, the use of contracts is growing as well as payments based on the quality and sanitary parameters of the milk. This movement is mainly pushed by stronger institutions and the infrastructure developed in recent years. Monetary incentives offered to dairy producers can encourage them to improve milk quality parameters overall. Botaro et al. (2013) have shown a direct association with a payment program based on milk quality and the reduction of both somatic cell count (SCC) and total bacterial count (TBC) in southern Brazil. Similar results were found by Nightingale et al. (2008) in the USA. Thus, we also assess the effects of different criteria for milk payments on efficiency.

Only in the southern region of Brazil, the main dairy production area in the country cooperatives collect $46.5 \%$ of the milk produced by the 300,000 small-scale family farms (IBGE 2018, 2006; OCB/Embrapa 2015). The national census of dairy cooperatives shows that they are losing market share in recent years ${ }^{6}$.

In 2002, the cooperatives in Brazil were responsible for $40 \%$ (5.3 billion liters) of the total milk collected in the whole country, while 36\% was collected in the country's southern region (Martins et al. 2004). This amount had generated a total revenue in the whole country of RS\$ 4.91 billion in 2002 or RS\$ 0.93 per liter ${ }^{7}$.

From the total milk collected by the cooperatives, only $44.2 \%$ was industrialized, thereof $49.4 \%$ by larger cooperatives. Cooperatives that industrialize less than one third of their milk earned a gross revenue of about RS\$ 0.46 per liter while those industrializing more than two thirds of their supplies received about RS\$ 1.24 per liter. Unfortunately, processing costs are not available for a comparison of profits. Nevertheless, these numbers represent the higher revenue generated through the value adding,

${ }^{4} \mathrm{FOB}$ - Free On Board, the exporter is responsible for all the costs until the goods are loaded in the agreed manner of transport via air/sea/land.

${ }^{5}$ The Brazilian quality and sanitary inspection systems are: SIF - Sistema de Inspeção Federal; SIE - Sistema de Inspeção Estadual; SIM - Sistema de Inspeção Municipal

${ }^{6}$ Two censuses were conducted so far, the first in 2002 and the second in 2015.

${ }^{7} 1$ US\$ = 2.697 RS\$ (average 2002); 1.993 RS\$ (average 2009); 3.39 RS\$ (average 2015); 3.45 RS\$ (average 2016); 3.19 RS\$ (average 2017). 
industrialization, and commercialization of processed products by larger cooperatives. It also highlights the importance of economies of scale in the dairy sector (Boysen and Schröder 2005; Mosheim and Lovell 2009).

The summary from the second national census of dairy cooperatives shows that the shares of total milk collected by Brazilian cooperatives decreased from 2002 to 35.5\%, despite an increase in total volume (8.54 billion liters) (OCB/Embrapa 2015). However, in the southern region, their participation increased by 10.5 percentage points in relation to 2002, showing their capacity to compete against the IOFs in the procurement of milk. However, these procurement and capacity shifts were accompanied by very low capacity utilization rates in the cooperatives in 2015. Their installed processing capacity was reported as a total of 28 million liters/day, with $47 \%$ of idle capacity (unused installed capacity) for the whole of Brazil. In the southern region, the capacity represents 14.1 million liters/day with $41 \%$ of idle capacity. Idle capacities can have a considerable impact on the efficiency levels as showed in the study of Hirsch et al. (2020). The total revenue of dairy cooperatives in Brazil was listed at around RS\$ 7.4 billion in 2015 or RS\$ 0.87 per liter. Less value was added per liter of milk compared to 2002. Cheeses and dairy drinks account for less than $16 \%$ of the total revenue, evidence of a low share of value-added products in their product portfolios.

\section{Materials and methods}

\section{Exponential stochastic frontier model}

A stochastic production frontier is used to estimate firms' TE. In particular, we assume that $\mathrm{N}$ firms can produce output $\mathrm{y}$ by using a vector of inputs $\mathbf{x} \in \mathrm{R}_{+}^{\mathrm{M}}$. The production frontier model (in logarithmic terms) can be written in the following way:

$$
y_{i}=\boldsymbol{x}_{i}^{\prime} \boldsymbol{\beta}+v_{i}-u_{i},
$$

where $y$ is the logarithm of the output of production, $x$ is a vector of the logarithm of inputs, $\boldsymbol{\beta}$ is a vector of parameters to be estimated, $v_{i}$ is a two-sided symmetric error term that accounts for white noise, and $u_{i}$ is a non-negative one-sided error component that measures inefficiency. The output is specified as the total revenue of a firm (in Reais), the vector of inputs $x$ consists of transport distance, labor in number of employees, and total production capacity. While the two-sided error term $v_{i}$ is assumed to follow a normal distribution with zero mean and variance $\sigma_{\mathrm{v}}^{2}$, we assume an exponential distribution for the inefficiency component $u_{i}$ with the rate parameter $\lambda_{\mathrm{i}}$ :

$$
u_{i} \sim \operatorname{Exp}\left(\lambda_{i}\right)
$$

TE estimates, which are bounded on the unit interval, can be obtained by taking the expectation of $\mathrm{e}^{-\mathrm{u}_{\mathrm{i}}}$. However, since the objective of this study is not only to examine the efficiency levels of dairy processing firms but also the determinants of their inefficiency, the rate parameter $\lambda_{\mathrm{i}}$ can be expressed as a function of firm-management characteristics as follows:

$$
\lambda_{i}=e^{z_{i}^{\prime} \delta}
$$

where $\mathbf{z}$ is a vector of potential determinants of TE and $\boldsymbol{\delta}$ is the $\mathrm{L} \times 1$ vector of parameters to be estimated. 


\section{Bayesian inference}

We use Bayesian techniques to estimate the model in Eqs. (1-3) (van den Broeck et al. 1994). Although Bayesian and frequentist techniques constitute two alternative approaches for measuring efficiency, we prefer the former mainly because latent variables such as the inefficiency component are integrated out from the likelihood by simply using simulation through the data augmentation technique, rather than numerical integration that the frequentist approach uses and can be unstable. Further advantages of the Bayesian approach include the incorporation of prior beliefs in a transparent way through the prior distributions and the construction of credible intervals based on the posterior draws rather than on multiple additional hypothetical samples.

The exponential stochastic frontier model was first introduced by Aigner et al. (1977) and Meeusen and van den Broeck (1977) and further extended by Koop et al. (1997) who allowed for the rate parameter of the distribution to be a function of firm characteristics in a panel data setting. The model was also used by Skevas et al. (2018) to calculate the total factor productivity of dairy farms. The likelihood of the model is written as:

$$
\begin{aligned}
p(\boldsymbol{y},\{\boldsymbol{u}\} \mid \boldsymbol{\theta}, \boldsymbol{X}, \mathbf{Z})= & \frac{\tau}{\mathrm{\tau} / 2} \exp \left\{-\frac{\mathrm{\tau}}{2} \sum_{i=1}^{N}\left(y_{i}-\boldsymbol{x}_{i}^{\prime} \beta+u_{i}\right)^{2}\right\} \\
& (2 \pi)^{N / 2} \\
& \times \lambda_{i} \exp \left\{-\lambda_{i} \sum_{i=1}^{N} u_{i}\right\}
\end{aligned}
$$

where $\lambda_{i}=e^{z_{i}^{\prime} \delta}$ as presented in Eq. (3).

The complete data likelihood consists of two terms: (i) the probability density function (pdf) of the normal distribution, which is due to the normality assumption of the error term $v_{i}$ and (ii) the pdf of the exponential distribution that is assumed for the inefficiency component $u_{i}$.

The prior density includes three terms: two multivariate normal densities for the vectors of parameters $\boldsymbol{\beta}$ and $\boldsymbol{\delta}$, where prior means are set equal to zero and the covariance matrices are specified as diagonal with a value of 1000 on the diagonal entries, and the inverse-Gamma density for the variance parameter $\sigma_{\mathrm{v}}^{2}$ with the shape and scale hyperparameters being set equal to 0.001 . All parameters to be estimated are collected in a vector $\boldsymbol{\theta}=\left[\boldsymbol{\beta}^{\prime}, \sigma_{\mathrm{v}}^{2}, \boldsymbol{\delta}^{\prime}\right]^{\prime}$. Then, the posterior distribution of the model is written as:

$$
\pi(\boldsymbol{\theta},\{\boldsymbol{u}\} \mid \boldsymbol{y}, \mathbf{X}, \mathbf{Z}) \propto p(\boldsymbol{y},\{\boldsymbol{u}\} \mid \boldsymbol{\theta}, \mathbf{X}, \mathbf{Z}) \times p(\boldsymbol{\theta})
$$

where $\mathrm{p}(\mathbf{y},\{\mathbf{u}\} \mid \boldsymbol{\theta}, \mathbf{X}, \mathbf{Z})$ is the complete data likelihood of the model, and $\mathrm{p}(\boldsymbol{\theta})$ is the prior density of the parameters to be estimated.

The model's parameters are estimated using the Markov chain Monte Carlo (MCMC) simulation as this is described in Koop et al. (1995), while the latent variable $u_{i}$ is integrated out of the likelihood using data augmentation (for details, see Tanner and Wong 1987).

Finally, estimation of the model is performed through BayES software which can be accessed free of charge at https://www.bayeconsoft.com/index.html. 


\section{Data and variable construction}

In 2008/09, the Paraná Economic and Social Development Institute (IPARDES) conducted a data collection to gather information from the dairy processing companies operating in the state. Data was collected about the characteristics of companies, the origin and quality control of raw milk, the technological structure, management practices, institutional choice, policy support, etc. The database is therefore a cross-section covering 1 year prior to data collection. It included 301 units corresponding to $96 \%$ of the 314 companies and $83 \%$ of the processed volume in the state.

From this database, we retained only 243 companies for our study, including 35 cooperatives and 208 IOFs. The remaining 58 companies were excluded from the sample because of excessive missing values on the variables of interest, or because of unreasonable/abnormal values caused by problems during the data collection. We also removed any dairies with their own herd (no transport involved) and those which processed from 225 to $3900 \mathrm{l}$ of milk per month (or 7.5 to $130 \mathrm{l}$ per day). They are mostly familybased farms, with no hired labor and no transport of milk, and generally they produce a small amount of cheese to sell to the neighborhood. For obvious problems of comparison, they were removed from the sample.

The distribution of the companies by yearly turnover size categories is shown in Table 1. The fourth column in this table presents the size categories adopted by the IPARDES in Paraná. More than $78 \%$ of the companies are classified as micro and small companies in the first three categories.

We specified the production function with one output (output index) and three inputs (total capacity of processing, labor, and transport). Raw milk is not included as an input because it is reflected by the $\times 3=$ total installed capacity of the companies since the latter includes the amount of milk per day that the companies process. As evidence, a correlation of 0.85 is found between $\times 3$ and the raw milk. The choice of variables is based on the literature on efficiency analysis, where industrial plants are the object of analysis, as well as the authors' knowledge of the under analysis. The database does not provide other inputs used in the production, which are commonly found in the literature (Baran 2013; Doucouliagos and Hone 2000; Ferrier and Porter 1991; Soboh et al. 2014), like energy and consumables for example, and it does not provide the total revenue of companies for confidentiality purposes".

Therefore, we used an output index, represented in Brazilian currency (R\$ Reais 1000), the most accurate approximation of the total outputs produced by each company. It is specified in Eq. (1) and its estimation is based on other known variables, such as the monthly mean volume collected over the last 12 months, the rate of the specific products produced by the company as available in the dataset, the volume of

Table 1 Size categories of companies in the sample

\begin{tabular}{llll}
\hline Size category & Frequency & Percent & IPARDES categories \\
\hline 1. Below $R \$ 360,000$ & 104 & 42.8 & Micro \\
2. From $R \$ 360,001$ to $R \$ 1,200,000$ & 61 & 25.1 & Micro \\
3. From $R \$ 1,200,001$ to $R \$ 2,400,000$ & 25 & 10.3 & Small \\
4. From $R \$ 2,400,001$ to $R \$ 10,500,000$ & 36 & 14.8 & Medium \\
5. From $R \$ 10,500,001$ to $R \$ 60,000,000$ & 11 & 4.5 & Medium/large \\
6. Above $R \$ 60,000,001$ & 6 & 2.4 & Large \\
\hline
\end{tabular}


milk necessary to produce each specific product, and their respective prices in that year. With this estimation, we can capture the efficiencies related to the chosen mix of products and their respective volumes. The use of physical values as outputs, though rather seldom, deems appropriate to display the stochastic production frontier as an estimate for the technical relation between inputs and outputs. It has been also applied in the existing literature (Kumbhakar et al. 2009; Mayen et al. 2010; Omondi et al. 2017). However, quantities may hide information on products' value added, innovations, regional dominance, and other factors influencing prices and hence revenues, whether up or down. Changes may occur for the most technically advanced companies, but we do not expect many of them, ensuring the reliability of this study. Hence, the results should be interpreted with some caution.

The inputs specified in the $\mathbf{X}$ vector in Eq. (1) are the following:

$\mathrm{x}_{1}=$ "Total capacity of processing" represents the full capacity in liters per month of the processing plants, which is also a proxy for capital;

$\mathrm{x}_{2}=$ "Labor", represented by the total number of employees in the company. The labor variable represents the number of employees, as wages and/or salaries are not available. Such a specification has also been used by Brümmer et al. (2002), Doucouliagos and Hone (2000), and Ferrier and Porter (1991), who also measured output in monetary terms; $\mathrm{x}_{3}=$ "Transport" represents the maximum distance (in $\mathrm{km}$ ) that each company has to travel in order to collect the milk from the farthest farmer. This variable is included because the dairy sector is very demanding in terms of transport since milk, as a perishable product, has to be collected frequently, which means every 2 days in most cases. Companies processing milk exclusively from their own herd have a value of 0.01 .

Those were the best inputs in the dataset representing the production function. In this study, the production function is specified in a Cobb-Douglas functional form ${ }^{8}$.

Table 2 provides the description of the output, input, and $Z_{\mathrm{i}}$ variables. It shows cooperatives larger than IOFs.

Finally, the $\mathbf{z}$ vector in Eq. (3) includes four variables:

$z_{1}=$ "Used capacity of the plant," defined as the percentage of the used capacity/total capacity; $z_{2}=$ A dummy for "cooperatives";

$z_{3}=$ A dummy representing any "different criteria of payment" different from volume of milk; $z_{4}=$ Three dummy variables are used for the "type of inspection service" adopted, one for SIF which is the most restrictive and rigorous with 77 companies in the sample, one for SIM which is the least restrictive with 62 companies in the sample, and one

\footnotetext{
${ }^{8}$ The translog would be preferred since it is a flexible functional form that does not impose any restrictions on substitution possibilities between inputs and outputs. However, formal model comparisons based on Bayes factors suggest that the data favor the Cobb-Douglas specification against the translog. The results from the two specifications along with the model comparison quantities are presented in Table 6 in the Appendix.
} 
Table 2 Descriptive statistics of the output and inputs

\begin{tabular}{|c|c|c|c|c|c|}
\hline \multicolumn{3}{|c|}{ Variable } & \multirow{2}{*}{$\begin{array}{l}\text { Full sample } \\
(n=243) \\
\text { Mean (Std. dev.) }\end{array}$} & \multirow{2}{*}{$\begin{array}{l}\text { Cooperatives } \\
(n=35) \\
\text { Mean (Std. dev.) }\end{array}$} & \multirow{2}{*}{$\begin{array}{l}\text { IOFs } \\
(n=208) \\
\text { Mean (Std. dev.) }\end{array}$} \\
\hline & & Unit & & & \\
\hline & \multicolumn{5}{|l|}{ Frontier } \\
\hline y & Output & $1000 \mathrm{R} \$$ & $\begin{array}{l}684,628.50(2,268, \\
836.00)\end{array}$ & $\begin{array}{l}1,685,719(5,255, \\
695)\end{array}$ & $\begin{array}{l}516,175.70(1,132, \\
705.00)\end{array}$ \\
\hline$x_{1}$ & Transport & $\mathrm{km}$ & $67.78(99.58)$ & 82.09 (184.71) & $65.37(77.13)$ \\
\hline$x_{2}$ & Labor & Persons & $24.96(51.76)$ & $38.77(99.1)$ & $22.63(38.48)$ \\
\hline \multirow[t]{2}{*}{$x_{3}$} & Total capacity & 10001 & $1,018,322(2,454,208)$ & $\begin{array}{l}1,754,338(4,623 \\
248)\end{array}$ & $894,473(1,850,341)$ \\
\hline & \multicolumn{5}{|l|}{ TE model } \\
\hline$z_{1}$ & Used capacity & $\%$ & $0.5(0.23)$ & $0.48(0.25)$ & $0.5(0.23)$ \\
\hline$z_{2}$ & Cooperatives & Dummy & $0.14(0.35)$ & & \\
\hline$z_{3}$ & $\begin{array}{l}\text { Different payment } \\
\text { criteria }\end{array}$ & Dummy & $0.83(0.38)$ & $0.6(0.5)$ & $0.87(0.34)$ \\
\hline \multirow[t]{4}{*}{$\mathrm{z}_{4}$} & \multirow{4}{*}{$\begin{array}{l}\text { Type of inspection } \\
\text { service }\end{array}$} & \multicolumn{4}{|c|}{3 dummies } \\
\hline & & SIM & $0.26(0.44)$ & $0.43(0.5)$ & $0.23(0.42)$ \\
\hline & & SIE & $0.43(0.5)$ & $0.34(0.48)$ & $0.44(0.5)$ \\
\hline & & SIF & $0.32(0.47)$ & $0.23(0.43)$ & $0.33(0.47)$ \\
\hline
\end{tabular}

for SIE which is the mid-term with 104 companies in the sample. SIF is used as the base category

Some theoretically important variables for efficiency such as firm age and provenances of capital, among others, were also included in the initial model specification but later dropped, not only due to being insignificant but most importantly, because their chains did not converge.

\section{Results and discussion}

\section{Production frontier and scale}

Table 3 reports the results of the posterior means, standard deviations, and $90 \%$ credible intervals with respect to inputs and the variance parameters. The elasticities of labor and total capacity are significant as their respective credible intervals do not contain zero and positively fulfill the monotonicity condition. The positive output elasticities in respect of these inputs indicate that if labor and total capacity increase by $1 \%$, output grows by $0.33 \%$ and $0.79 \%$ respectively, all other conditions being equal.

The result on the scale elasticity of 1.12 corroborates this, revealing that companies operate under increasing returns of scale, which suggests that there is some potential for firm growth or structural change. A study on the Chilean dairy sector has also shown that $72.7 \%$ of firms are working with increasing returns to scale (Lakner et al. 2017). This result suggests that firms have a margin to grow through organic expansion and/or mergers, continuing the process of consolidation of the dairy sector in Brazil. Nderitu and Ndiritu (2018) suggests that mergers and acquisitions may lead to an increase of companies' market shares, create market dominance, and have a significant positive effect on product price in the processed milk market in developing economies. 
Table 3 Posterior means, standard deviations, and 90\% intervals with respect to inputs, the determinants of lambda, and the variance parameter

\begin{tabular}{llll}
\hline Variable & Mean & Std. dev. & $\mathbf{9 0 \%}$ credible interval \\
\hline Constant & 0.292 & 0.050 & {$[0.208,0.374]$} \\
Transport costs & 0.005 & 0.014 & {$[-0.018,0.028]$} \\
Labor & 0.325 & 0.048 & {$[0.246,0.404]$} \\
Production capacity & 0.791 & 0.038 & {$[0.728,0.852]$} \\
Constant & 1.291 & 0.436 & {$[0.700,2.135]$} \\
Used capacity & 1.789 & 0.243 & {$[1.417,2.211]$} \\
Dummy for cooperatives & 1.014 & 0.492 & {$[0.282,1.885]$} \\
Dummy for different payment criteria & 0.066 & 0.296 & {$[-0.445,0.529]$} \\
SIE & 0.281 & 0.311 & {$[-0.244,0.770]$} \\
SIM & 0.738 & 0.424 & {$[0.040,1.436]$} \\
$\sigma_{v}$ & 0.356 & 0.027 & {$[0.314,0.401]$} \\
\hline
\end{tabular}

Examples of mergers of dairy processing companies are present all over the world, such as Fonterra, Arla Foods, Dairy Farmers of America (DFA), Friesland-Campina, Deutsches Milchkontor (DMK), Lactalis/Parmalat, and AMUL, among others.

The drivers of such mergers were the structural changes in the food industry, consolidation of the productive sector, necessity of technological progress, high price volatility in the 1990s, and little growth in consumption. These drivers increased competitiveness and forced firms, mostly cooperatives, to gain scale and improve their operational efficiency in order to be competitive (Chaddad 2007a). Similar developments have been observed in Brazil over the past several years. Nevertheless, the proportion of organizations merging remains low, either because of disorganization in the sector or internal conflicts (Beber et al. 2019).

\section{Technical efficiency}

Average $\mathrm{TE}^{9}$ for all firms is $77 \%$ meaning that the actual output is $23 \%$ below its potential, which implies that output could, on average, be increased by approximately $31.6 \%$ (i.e., $((100 / 77-1) \times 100))$. This percentage represents the relative measure of TE in comparison to the most efficient companies in the respective sample. Figure 2 presents a histogram of the distribution of the companies' TE scores.

Most of the companies are concentrated in the upper levels of efficiency. However, a significant number of companies are also seen at the very low levels, where 45 companies are below 0.6, indicating problems for achieving higher efficiency levels. In Table 4, the mean efficiency of companies of each size category is represented. It shows the larger companies in the three upper categories as being more efficient. The heterogenous results on TE suggest the coexistence of a "dual structure" in the milk processing industry in Paraná. Companies show a high level of technology adoption, marketing campaigns, professionalism, and larger scales on the one side. On the other side, there are companies based on small family farms and producers' cooperatives for milk collection.

\footnotetext{
${ }^{9}$ The mean value of TE is obtained by taking the mean of minus the exponential of the posterior draws of $u_{-} \mathrm{i}$ across iterations and firms.
} 


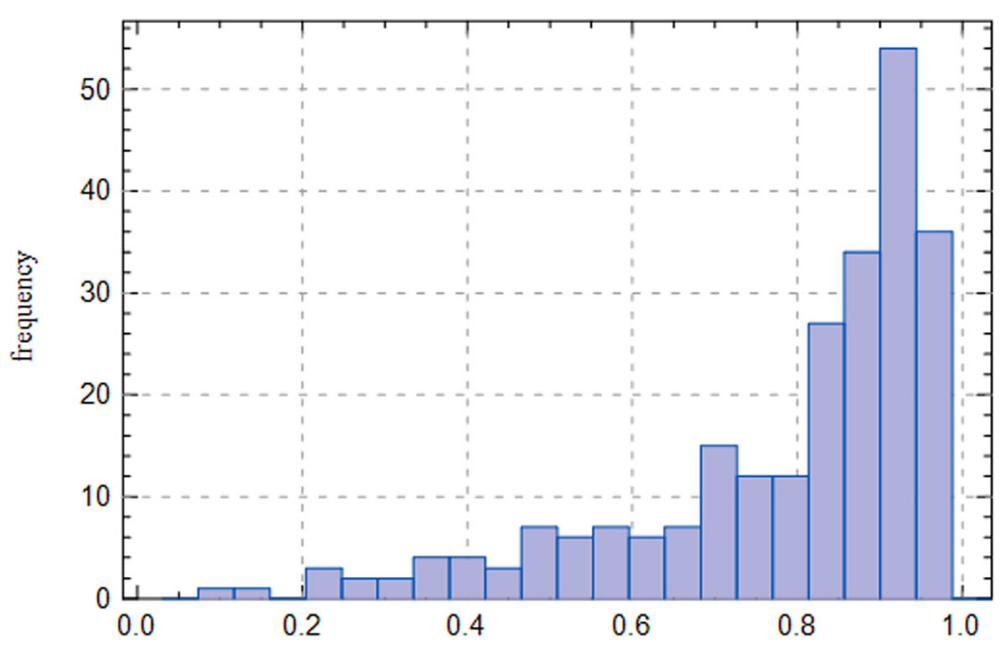

Fig. 2 Histogram of technical efficiency scores

These companies remain active for any reason that may guarantee them a market for their products. It could be the remoteness and the anti-competitive effects in some areas, ensured by a monopolistic/monopsonistic position (Hansmann 1996) as evidenced by Revoredo-Giha and Renwick (2016) in the Malawian dairy sector. They showed that the processing industry has either market power in both the output and input market and/or a niche market. The same is also evidenced by different studies of SMEs in the food sector in Europe (Gardebroek et al. 2010; Ilbery and Kneafsey 1999; Olsen et al. 2012; Shaw et al. 1999). These firms are offering the sole choice of dairy products to some costumers and, in some cases, acting as the only buyers of milk from the farmers. In the same direction, Lerman and Parliament (1991), using financial indicators, also reveal that small-regional dairy cooperatives have higher profitability and overall performance than larger ones.

Adding to this, in Paraná, some companies were created with the sole purpose of taking advantage of governmental programs for institutional purchase, like the "Programa Leite das Crianças" (Children's Milk Program) or the "Programa Leite do Paraná" (Paraná's Milk Program). Generally, such companies are new to the market and have government purchases as their core business, which generates strong dependence. In these cases, there are fewer incentives to professionalize the management, design marketing strategies, or become more efficient.

Strong criticism on the effectiveness of such government incentives in the agricultural sector is attributed to Schultz (1964). In his "poor, but efficient" hypothesis, he states

Table 4 Mean TE of each size category of companies

\begin{tabular}{llll}
\hline Size category & Mean TE. & Std. Dev. & Frequency \\
\hline 1. Below $R \$ 360,000$ & 74.13 & 22.38 & 104 \\
2. From $R \$ 360,001$ to $R \$ 1,200,000$ & 77.16 & 19.85 & 61 \\
3. From $R \$ 1,200,001$ to $R \$ 2,400,000$ & 76.64 & 17.16 & 25 \\
4. From $R \$ 2,400,001$ to $R \$ 10,500,000$ & 82.84 & 11.53 & 36 \\
5. From $R \$ 10,500,001$ to $R \$ 60,000,000$ & 90.78 & 4.09 & 11 \\
6. Above $R \$ 60,000,001$ & 84.71 & 18.84 & 6 \\
\hline
\end{tabular}


that the provision of agricultural incentives will be ineffective in improving productivity and incomes when investment opportunities are limited. For instance, in developing and emerging countries, such opportunities could be limited due to technological access and good managerial practices or even credit access. Therefore, the end of governmental incentives generally determines the end of such firms (Beber et al. 2018).

\section{Determinants of efficiency}

Since one of the main contributions of this study lies in the explanation of TE heterogeneity due to firm-specific characteristics, we derived the marginal effects of the variables in $\mathbf{z}$ on $\mathrm{TE}^{10}$. These marginal effects are calculated at the mean values of the continuous variables, while for the dummy variables they are calculated for discrete changes from 0 to 1 and are presented in Table 5. Additionally, although there exists a debate on whether marginal effects should be calculated unconditionally (Wang 2002) or conditionally (Kumbhakar and Sun 2013) on the composed residual, we choose to calculate them unconditionally on the composed residual, because inefficiency itself is also obtained unconditional on the composed residual, as it is the case with the data augmentation techniques used in the utilized Bayesian framework. Three out of four marginal effects are statistically significant. The payment criteria for different volumes of milk is not significant, so firms are not more or less efficient in paying prices to producers based on quality or other characteristics of the milk. This characteristic might have an effect on farmers' efficiency, which should be further investigated.

\section{Organizational form}

Cooperatives are, in general, $0.09 \%$ more efficient than IOFs. The average efficiency of cooperatives is 83.4 , while that of IOFs is $76.4^{11}$. The descriptive statistics in Table 2 shows that cooperatives have 3.3 times higher outputs than IOFs, but both have similar used capacities of around 50\%. At the same time, cooperatives have only 1.26 times higher the maximum distance of transport and 1.71 times higher the labor. That means that cooperatives are indeed using their inputs more efficiently than IOFs, contradicting Hind (1999) who argued that cooperatives are less efficient in input use. On the other hand, it corroborates the study of Soboh et al. (2014) which, using data from European dairies, showed that cooperatives have higher physical productivity but are also more marketing efficient. The alignment of the objectives of the cooperative and its members can provide an advantage over the IOFs (Bontems and Fulton (2005). Reduction of risk (confidence) and better technical support might also account for the higher quality products supplied by the cooperatives' farmers (Cechin et al. 2013). This result also highlights the importance of scale in agriculture and that cooperatives offer a strategic solution to increase scale (Linn and Maenhout 2019).

Weak institutions and their associated market imperfections, especially in rural zones of developing and emerging economies, raise the costs of market contracting in

\footnotetext{
${ }^{10}$ Note that the variables in $\mathrm{z}$ associated with a positive parameter have a positive impact on lambda, a negative impact on inefficiency (given that inefficiency $=1 /$ lambda) and consequently a positive effect on efficiency.

${ }^{11}$ If we take the mean of minus the exponential of the posterior draws of $u_{-} i$ only across iterations, we get an efficiency score for each firm in the sample. Then, we can take (a) the mean of the efficiency scores for cooperatives and report it; (b) the mean for IOFs and report it; (c) the mean for firms adopting the SIE and report it; and (d) the mean for firms adopting the SIF and report it.
} 
Table 5 Marginal effects of the variables in Z on TE

\begin{tabular}{llll}
\hline Variable & Mean & Std. dev. & $\mathbf{9 0 \%}$ credible interval \\
\hline Used capacity & 0.219 & 0.032 & {$[0.166,0.272]$} \\
Dummy for cooperatives & 0.092 & 0.035 & {$[0.033,0.147]$} \\
Dummy for different payment criteria & 0.010 & 0.036 & {$[-0.049,0.069]$} \\
SIE & 0.035 & 0.037 & {$[-0.028,0.095]$} \\
SIM & 0.078 & 0.043 & {$[0.005,0.145]$} \\
\hline
\end{tabular}

Paraná's dairy sector (Beber et al. 2019). Thus, transactions within cooperatives are likely to provide higher organizational efficiency, according to Hansmann (1996). The same author argued that cooperatives might enjoy monopsony power to some extent, due to the relative high distances from farmers to competing processing companies in rural zones and the high perishability of the milk. Further studies accounting for such contractual costs between farmers and cooperatives or IOFs and the cooperatives' monopsony power should provide further evidence on such hypotheses.

The more conservative financial structure of the cooperatives may also bring advantages to dealing with such changes of context, crisis, and policies. Soboh et al. (2011) have demonstrated that cooperatives have a stronger financial position than IOFs and are well equipped for making any necessary investments for such adaptation. They are on average less profitable but pay higher prices to farmers, are more attractive, and operate more efficiently. However, different cooperative ownership structures are emerging in the agri-food section in an attempt to seek external capital sources for largescale investments (Grashuis 2018). The loss of decision power by the farmers inside such structures remains a question for the long-term survival of these cooperatives and promotes an intense debate in the literature (Chaddad and Cook 2004).

\section{Used capacity in processing plants}

As expected, higher used capacity in processing plants increases the efficiency of the firms. In this regard, an increase in used capacity of $1 \%$ leads to an efficiency increase of $0.22 \%$. It is also very likely to affect the efficient use of the input total capacity. Figure 3 shows the strong relation between TE and the used capacities.

It is important to highlight that we assumed the production technology operating at static cost-minimizing input levels, where all inputs are fully adjusted to their long-run equilibrium levels within one period. However, "total capacity" could instead be assumed as a quasi-fixed input, i.e., not completely, instantaneously adjusted in response to changes in factor prices and at no cost. This would imply that companies presenting idleness in the short-term may not present it over the long term, as their total capacities are adjusted over time. A formal test of such long-term adjustment to this quasifixed factor (total capacity) would confirm if those companies are indeed overcapitalized and operating with inefficient idle capacities or, instead, achieving long-term equilibrium with total capacity optimally adjusted (Kulatilaka 1985; Morrison 1985). In the latter case, companies may still have idle capacity due to other management shortcomings, but its dimension would be rather smaller.

However, a previous study on the same area (Beber et al. 2019) provided us with a strong indication that idle capacities are mostly due to management shortcomings and 


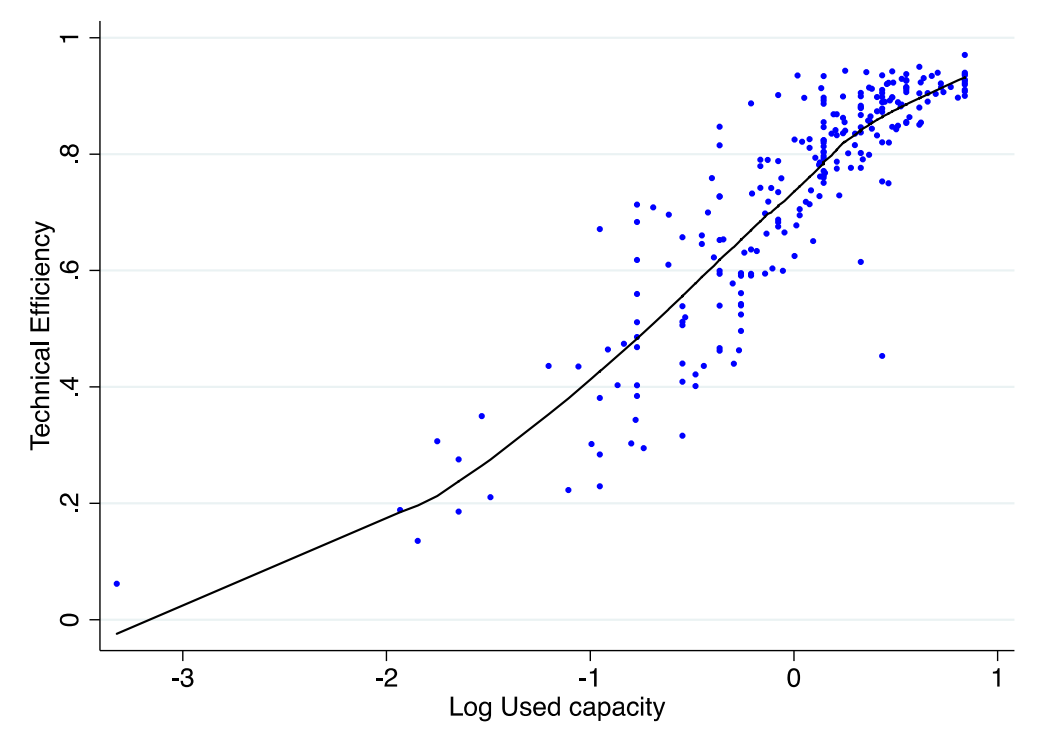

Fig. 3 Scatter plot of TE and (log) used capacity of processing companies

we therefore decided to include this variable in the efficiency model. In this parallel study, the authors conducted semi-structured interviews with the managers and directors of processing companies in this region, asking directly about the existence and sources of "idle capacities." Most of the interviewees confirmed the existence of longterm idle capacities (even in high-season periods) due to disputes in supply control, a lack of loyalty among suppliers and poor management planning of processing among others (Beber et al. 2019), reinforcing our decision. It therefore could not be considered a short-term effect of cyclical fluctuation. It is also not possible to attribute these "idle capacities" to an inflationary pressure on costs of changes in aggregate demand, as since 2009, inflation has been under control and demand for dairy products has been increasing in Brazil.

This indication of "over-capitalization" may also have an historical explanation. During the 1980s and 1990s, investment credits were given to cooperatives and other agricultural processing companies without technical and managerial support. So huge unplanned investments were made with these subsidized loans, with the building of large processing plants without any strategic plan for their supply or for the commercialization of their production. Idle capacities were therefore created (Escher 2011) which may persist over time (see descriptive statistics in Table 2). Indications of over-capitalization leading to idleness of dairy processing plants are also evidenced in the study of Furesi et al. (2013); however, the seasonal component indeed play a role in this case.

\section{Inspection services}

Contrary to what was expected, the companies linked to the inspection services that are more restrictive on sanitary and quality parameters for dairy products are shown to be less efficient. Firms that adopt the SIE do not exhibit statistically significant (in)efficiency differences when compared to those that adopt the SIF as the respected parameter estimate is statistically insignificant. However, the parameter with respect to SIM 
is positive and statistically significant, suggesting that firms that adopt the SIM are more efficient than those that adopt the SIF.

The marginal effects presented on Table 5 reveal that firms adopting the SIM are $7.8 \%$ more efficient than those adopting the SIF. The average efficiency of companies adopting SIE and SIF is similar, at 77.2; however, those adopting SIM have a higher score of 78.1.

A possible explanation for this result is the fact that more stringent sanitary conditions increase the use of factors such as labor, decreasing the efficiency of companies, especially related to the use of this input. More workers might be needed for companies to cope with the higher standards of SIF and SIE for instance. Another possible cause is that sanitary controls may not be the reason for the decrease in efficiency, but rather the market region. Companies adopting the SIM are only allowed to sell their products inside the municipality. Generally such companies are specialized in more specific added-value products, competing on higher margin products but at lower quantities than the large dairies. Mostly they do not compete for the low-added-value products such as drinking milk, butter, or powdered milk, for example, for production scale reasons. This result is probably explained by the portfolio of products produced to attend such markets, having higher added-value products like special cheeses, yogurts, dulce de leche, among others. For this reason, they may be competing in niches with products permitting them to achieve higher outputs with the same amount of inputs (Ilbery and Kneafsey 1999; Olsen et al. 2012; Shani and Chalasani 1992; Shaw et al. 1999). Further studies on such niches should be conducted to confirm this hypothesis.

\section{Conclusions and implications}

This article specifies a stochastic production frontier and estimates the TE and its determinants for processing companies in the State of Paraná in southern Brazil. The determinants of inefficiency captured in this study relate to reducing their idle capacities and management shortcomings in order to considerably improve efficiency. Another important result concerns the adoption of the different inspection services. More restrictive ones regarding the sanitary characteristics of products decrease the efficiency of companies. Cooperatives are in general more efficient than IOFs.

Cooperatives have developed a functioning business model which shows that inclusion of cooperative members is possible, despite particular problems which they must overcome, such as higher transaction costs and the five vaguely defined property rights inherent to the traditional cooperatives. Descriptive results show that cooperatives in Paraná have higher outputs, and the determinants of efficiency also show cooperatives to be more efficient. They operate at a more efficient scale than the IOFs but also add more value to the final products. Despite being more efficient, this organizational form provides several benefits to the farmers besides the monetary, and therefore should be supported by specific public policies.

Our results suggest that the investigated cooperatives might behave slightly differently to those of other cooperatives analyzed in the literature: In Brazil, since the mid1990s, a globalization/modernization movement of the dairy sector has been observed, with consequent increased competitive pressures and concentration of processing companies. This movement can be attributed to several political and organizational factors 
such as the liberalization of markets in Brazil that removed government control over milk prices, the reduction of trade barriers, the creation of Mercosur-with Argentina and Uruguay having a much more developed dairy sector competing in Brazil-and the installation of large retailers undermining the local character of cooperatives, among others (Beber et al. 2018). Companies, and specifically the cooperatives, are merging and seemingly behaving in a more profit-oriented fashion, which extends the existing view on cooperatives for this specific case of Brazil.

Considering a composite objective measure could be the subject of future research in the comparison of cooperatives and IOFs. In this paper, we have used the assumption of profit maximization. It should be noted in a broader sense that cooperatives have a larger utility function beyond pure profit maximization, which can be captured by qualitative variables like preferences or attitudes. Still, profit takes a large proportion of the utility. Since these variables were not available, this paper had to focus on the pure economic aspects of the utility function, which is also done in other studies in the field.

Since companies operate under increasing returns to scale, a planned increase in the size of companies through mergers and/or acquisitions or organic growth would lead operations at a more efficient scale, specifically for the IOFs in our sample which are smaller than the cooperatives, always carefully avoiding idleness. The avoidance of unplanned overinvestments that might create such idleness is crucial. Outsourcing and strategic alliances may also reduce idle capacity in dairy firms and increase their competitiveness, particularly when combined with technical assistance measures to reduce production seasonality among farmers. Policies promoting technical assistance and facilitating merges and credit lines for expansion would benefit companies in this regard.

Despite companies which adopt SIM are shown to be more efficient, this does not mean that less concern for sanitary measures is the reason for such higher efficiency. The literature shows evidence that higher sanitary measures may lead stakeholders to access further markets in modern supply chains (Dries et al. 2009), but the necessary investments to meet such requirements may also lead companies to exit (Noev et al. 2009). Some firms access more markets by achieving higher standards, but small companies go bankrupt when such standards are simply imposed. With the implementation of the new national inspection system in Brazil, a time for adaptation and a follow-up of the transition process must therefore be carefully considered in order to avoid unnecessary prejudices. Therefore, governmental support for the transition period must be provided in order to avoid such exclusion.

Our results provided policymakers and managers with important information with which to design measures to improve firm performance and minimize the risk of hardship caused by the shutdown of dairy enterprises in rural communities. Despite some changes having actually occurred in the dairy sector in southern Brazil since the data was collected, they are not radical, as can be observed in the "Study area" section. Companies are still facing the challenges which were present in 2009, especially because since then, the crises of 2008 and 2015 that affected several countries have slowed down investments and consequent progress. The lower competitive pressures in the dairy sector in this zone, when compared to other sectors such as soybean and meat, for example, have also slowed the 
evolution process. Thus, companies remain with inefficiencies and the need to overcome them, ensuring these conclusions are relevant.

Other countries and Brazilian regions with similar characteristics can also benefit from this study's conclusions, which is the case of Minas Gerais and the northeastern states, for instance. The dairy production in these states is also centered in family farms, cooperatives, and SMEs, and also has quality and sanitary problems and the same inspection services, likely facing similar challenges to improve efficiency. The same is valid for the dairy sector of other countries, especially for those dairy production zones in a lower or analogous socioeconomic and structural level of development to southern Brazil. Policy makers and managers planning to deal with the inefficiencies in their dairy industry can learn from these results, especially regarding the benefits of cooperatives and the problem of idleness in dairy processing plants.

This study provides an insightful contribution to the literature on firm organization in the agribusiness sector with the assessment of dairy processing companies in southern Brazil. It contributes especially to the debates about the performances of the cooperatives, showing cooperatives to be more efficient than IOFs. Overall, our results suggest a set of determinants that should be targeted at actions aiming to improve the TE of dairy processing companies in southern Brazil, a prominent strong competitor in the global dairy chain.

\section{Appendix}

Table $\mathbf{6}$ Results from the Cobb-Douglas and translog specifications

\begin{tabular}{|c|c|c|c|c|c|c|}
\hline \multirow[b]{2}{*}{ Variable } & \multicolumn{3}{|c|}{ Cobb-Douglas } & \multicolumn{3}{|l|}{ Translog } \\
\hline & Mean & Std. dev. & $90 \%$ C.I. & Mean & Std. dev. & $90 \%$ C.I. \\
\hline Constant & 0.292 & 0.050 & {$[0.208,0.374]$} & 0.115 & 0.067 & {$[0.005,0.226]$} \\
\hline Tr. costs & 0.005 & 0.014 & {$[-0.018,0.028]$} & 0.077 & 0.031 & {$[0.025,0.128]$} \\
\hline Labor & 0.325 & 0.048 & {$[0.246,0.404]$} & 0.224 & 0.054 & {$[0.135,0.313]$} \\
\hline Prod. cap. & 0.791 & 0.038 & {$[0.728,0.852]$} & 0.801 & 0.038 & {$[0.739,0.864]$} \\
\hline Tr. costs $x$ labor & - & - & - & -0.025 & 0.022 & {$[-0.061,0.011]$} \\
\hline Tr. costs $x$ Prod. cap. & - & - & - & 0.039 & 0.012 & {$[0.018,0.059]$} \\
\hline Labor x Prod. cap. & - & - & - & -0.138 & 0.079 & {$[-0.268,-0.008]$} \\
\hline Tr. costs ${ }^{2}$ & - & - & - & 0.003 & 0.012 & {$[-0.017,0.023]$} \\
\hline Labor $^{2}$ & - & - & - & 0.267 & 0.109 & {$[0.089,0.447]$} \\
\hline Prod. cap. ${ }^{2}$ & - & - & - & 0.069 & 0.062 & {$[-0.032,0.171]$} \\
\hline$\sigma_{v}$ & 0.356 & 0.027 & {$[0.314,0.401]$} & 0.354 & 0.023 & {$[0.317,0.393]$} \\
\hline Constant & 1.291 & 0.436 & {$[0.700,2.135]$} & 1.736 & 0.470 & {$[1.011,2.545]$} \\
\hline Used capacity & 1.789 & 0.244 & {$[1.417,2.211]$} & 1.894 & 0.276 & {$[1.467,2.363]$} \\
\hline D. cooperatives & 1.014 & 0.492 & {$[0.282,1.885]$} & 0.709 & 0.510 & {$[-0.055,1.603]$} \\
\hline D. payment criteria & 0.066 & 0.296 & {$[-0.445,0.529]$} & -0.185 & 0.320 & {$[-0.732,0.317]$} \\
\hline SIE & 0.281 & 0.311 & {$[-0.244,0.770]$} & 0.243 & 0.337 & {$[-0.312,0.782]$} \\
\hline SIM & 0.738 & 0.424 & {$[0.040,1.436]$} & 0.615 & 0.465 & {$[-0.154,1.375]$} \\
\hline Marg. log lik. & \multicolumn{3}{|c|}{-192.107} & \multicolumn{3}{|l|}{-223.681} \\
\hline Post. prob. & \multicolumn{3}{|l|}{1.000} & \multicolumn{3}{|l|}{0.000} \\
\hline
\end{tabular}




\section{Abbreviations}

FOB: Free On Board; GVIP: Gross Value of Industrial Production; IOF: Investor-owned firm; IPARDES: Paraná Economic and Social Development Institute; MAPA: Ministry of Agriculture, Livestock and Supply; SCC: Somatic cell count; SFA: Stochastic frontier analysis; SIE: State Inspection Service; SIF: Federal Inspection Service; SIM: Municipal Inspection Service; SISBI-POA: Brazilian System of Animal Products Inspection; SME: Small and Medium Enterprise; TBC: Total bacterial count; TE: Technical efficiency; UHT: Ultra-high temperature

\section{Supplementary Information}

The online version contains supplementary material available at https://doi.org/10.1186/s40100-021-00195-3.

\section{Additional file 1.}

\section{Acknowledgements}

We would like to thank the "Institute of Economic and Social Development of Paraná (IPARDES)" for providing us the database used for the analysis.

\section{Authors' contributions}

All authors read and approved the final manuscript

\section{Funding}

CAPES/CNPq Science without Borders - Brazil. Open Access funding enabled and organized by Projekt DEAL.

\section{Availability of data and materials}

The data that support the findings of this study are available from "Institute of Economic and Social Development of Paraná (IPARDES)" but restrictions apply to the availability of these data, which were used under license for the current study, and so are not publicly available. Data are however available from the authors upon reasonable request and with permission of "Institute of Economic and Social Development of Paraná (IPARDES)".

\section{Declarations}

\section{Competing interests}

The authors declare that they have no competing interestsinterests.

\section{Author details}

${ }^{1}$ Department of Agricultural Economics and Rural Development, Georg-August-University Göttingen, Platz der Göttinger Sieben 5, 37073 Gottingen, Germany. ${ }^{2}$ Chair of Agricultural Economics, Agricultural and Environmental Science Faculty, University of Rostock, Justus-von-Liebig-Weg 7, 18059 Rostock, Germany. ${ }^{3}$ Department of Food Business and Development, Cork University Business School, West Wing, Main Quadrangle, University College Cork, Cork, Ireland T12 K8AF.

Received: 25 August 2020 Revised: 4 May 2021 Accepted: 21 May 2021 Published online: 14 June 2021

\section{References}

Aigner D, Lovell CAK, Schmidt P (1977) Formulation and estimation of stochastic frontier production function models. J. Econom. 6:21-37 https://doi.org/10.1016/0304-4076(77)90052-5

Baran J (2013) Efficiency of the production scale of Polish dairy companies based on Data Envelopment Analysis. Acta Sci Pol Oeconomia 12:5-13

Beber CL, Carpio AFR, Almadani MI, Theuvsen L (2019) Dairy supply chain in Southern Brazil: barriers to competitiveness. Int Food Agribus Manag Rev:1-24 https://doi.org/10.22434/FAMR2018.0091

Beber CL, Theuvsen L, Otter V (2018) Organizational structures and the evolution of dairy cooperatives in Southern Brazil: a life cycle analysis. J Co-op Organ Manag. https://doi.org/10.1016/j.jcom.2018.06.003

Beckmann V (2000) Transaction costs and institutional choice in agriculture - between market, hierarchy and cooperation (in German), Berliner Schriften zur Kooperationsforschung. Ed. Sigma, Berlin

Berdegué J (2001) Cooperating to compete: associative peasant business firms in Chile. Wageningen University, Wageninge

Bontems P, Fulton M (2005) Organizational structure and the endogeneity of cost: Cooperatives, For-Pro...t Firms and the cost of procurement $1-37$

Botaro BG, Gameiro AH, dos Santos MV (2013) Quality based payment program and milk quality in dairy cooperatives of Southern Brazil: an econometric analysis. Sci Agric 70:21-26

Boysen O, Schröder C (2005) Economies of Scale in der Produktion versus Diseconomies im Transport: zum Strukturwandel in der Milchindustrie, Diskussionsbeiträge des Fachbereichs Wirtschaftswissenschaft der Freien Universität Berlin Volkswirtschaftliche Reihe. Freie Univ, Berlin

Boyle GE (2004) The economic efficiency of Irish dairy marketing co-operatives. Agribusiness 20:143-153 https://doi.org/10.1 002/agr.20000

Brümmer B, Glauben T, Thijssen G (2002) Decomposition of productivity growth using distance functions: the case of dairy farms in three European countries. Am J Agric Econ 84:628-644

Carvalho VRF (2008) Tese - Reestruturação do Sistema Lácteo Mundial: Uma Análise da Inserção Brasileira. Universidade Estadual de Campinas - Instituto de Economia, Campinas

Cechin A, Bijman J, Pascucci S, Zylbersztajn D, Omta O (2013) Quality in Cooperatives versus investor-owned firms: evidence from broiler production in Paraná, Brazil. Manag Decis Econ 34:230-243 https://doi.org/10.1002/mde.2586 
Chaddad (2007a) Cooperativas no agronegócio do leite: mudanças organizacionais e estratégicas em resposta à globalização. Organ. Rurais Agroindustriais 9:69-78

Chaddad (2007b) The evolution of Brazilian dairy cooperatives: a life cycle approach. In: XLV Congresso Da Sober," Conhecimentos Para Agricultura Do Futuro". Londrina, pp. 22-25

Chaddad FR, Cook ML (2004) Understanding new cooperative models: an ownership-control rights typology. Appl Econ Perspect Policy 26:348-360 https://doi.org/10.1111/j.1467-9353.2004.00184.x

Chaddad FR, Jank MS (2006) The evolution of agricultural policies and agribusiness development in Brazil. Choices 21:85-90

Chagwiza C, Muradian R, Ruben R (2016) Cooperative membership and dairy performance among smallholders in Ethiopia. Food Policy 59:165-173 https://doi.org/10.1016/j.foodpol.2016.01.008

Cook ML (1995) The Future of U.S. Agricultural cooperatives: a neo-institutional approach. Am J Agric Econ 77:1153-1159 https://doi.org/10.2307/1243338

Doucouliagos H, Hone P (2000) The efficiency of the Australian dairy processing industry. Aust J Agric Resour Econ 44:423438

Dries L, Germenji E, Noev N, Swinnen JFM (2009) Farmers, vertical coordination, and the restructuring of dairy supply chains in Central and Eastern Europe. World Dev. 37:1742-1758 https://doi.org/10.1016/j.worlddev.2008.08.029

Escher F (2011) Os Assaltos do Moinho Satânico nos Campos e os Contramovimentos da Agricultura Familiar (Master in Rural Development). Universidade Federal do Rio Grande do Sul, Porto Alegre

FAOSTAT (2019) Food and Agriculture Organization of the United Nations. FAOSTAT Statistics Database [WWW Document]. URL http://www.fao.org/faostat/en/\#home. Accessed 18 Mar 2019

Ferrier GD, Porter PK (1991) The productive efficiency of US milk processing co-operatives. J Agric Econ 42:161-173

Franken JR, Cook ML (2013) Informing Measurement of Cooperative Performance, in: Interfirm Networks. Presented at the International Conferences on Economics and Management of Networks - EMNet, Springer, Agadir, Morocco, pp 209-226

Furesi R, Madau FA, Pulina P (2013) Technical efficiency in the sheep dairy industry: an application on the Sardinian (Italy) sector. Agric Food Econ. 1:4 https://doi.org/10.1186/2193-7532-1-4

Gardebroek C, Turi KN, Wijnands JHM (2010) Growth dynamics of dairy processing firms in the European Union. Agric Econ 41:285-291 https://doi.org/10.1111/j.1574-0862.2010.00447.x

Grashuis J (2018) Joint ownership by farmers and investors in the agri-food industry: an exploratory study of the limited cooperative association. Agric Food Econ 6:24 https://doi.org/10.1186/s40100-018-0118-0

Gupta K, Roy D (2012) Gains from coordination in milkfed dairy in Punjab. J Agribus Dev Emerg Econ 2:92-114 https://doi.org/10.1108/20440831211272571

Hansmann H (1996) The ownership of enterprise. The Belknap Press of Harvard University Press, Cambridge

Hind A (1999) Cooperative performance-is there a dilemma. J Coop. 14:30-43

Hirsch S, Hartmann M (2014) Persistence of firm-level profitability in the European dairy processing industry. Agric Econ 45: 53-63 https://doi.org/10.1111/agec.12129

Hirsch S, Mishra A, Möhring N, Finger R (2020) Revisiting firm flexibility and efficiency: evidence from the EU dairy processing industry. Eur Rev Agric Econ https://doi.org/10.1093/erae/jbz003

IBGE (2006) IBGE :: Instituto Brasileiro de Geografia e Estatística. Censo Agropecuário 2006. [WWW Document]. http://www.ibge.gov.br/home/ (Accessed 26 Oct 15).

IBGE (2017) IBGE :: Instituto Brasileiro de Geografia e Estatística. Censo Agropecuário 2017. [WWW Document]. http://www.ibge.gov.br/home/ Accessed 11 Apr 15

IBGE (2018) IBGE :: Instituto Brasileiro de Geografia e Estatística - Pesquisa da Pecuária Municipal [WWW Document]. http://www.ibge.gov.br/home/ (Accessed 26 Oct 15).

Ilbery B, Kneafsey M (1999) Niche markets and regional speciality food products in Europe: towards a research agenda. Environ Plan Econ Space 31:2207-2222 https://doi.org/10.1068/a312207

IPARDES (2010) Caracterização da Indústria de Processamento e Transformação do Leite no Paraná. Instituto Paranaense de Desenvolvimento Econômico e Social - IPARDES, Curitiba

Koop G, Osiewalski J, Steel MFJ (1997) Bayesian efficiency analysis through individual effects: hospital cost frontiers. J Econom. 76:77-105 https://doi.org/10.1016/0304-4076(95)01783-6

Koop G, Steel MF, Osiewalski J (1995) Posterior analysis of stochastic frontier models using gibbs sampling. Comput Stat. 10: 353-373

Kulatilaka N (1985) Tests on the validity of static equilibrium models. J Econom. 28:253-268

Kumbhakar SC, Sun K (2013) Derivation of marginal effects of determinants of technical inefficiency. Econ Lett 120:249-253 https://doi.org/10.1016/j.econlet.2013.04.041

Kumbhakar SC, Tsionas EG, Sipiläinen T (2009) Joint estimation of technology choice and technical efficiency: an application to organic and conventional dairy farming. J Product Anal 31:151-161 https://doi.org/10.1007/s11123$008-0081-y$

Lakner S, Brenes-Muñoz T, Brümmer B (2017) Technical Efficiency in Chilean Agribusiness Industry: A Metafrontier Approach. Agribusiness. https://doi.org/10.1002/agr.21493

Lerman Z, Parliament C (1991) Size and industry effects in the performance of agricultural cooperatives. Agric Econ 6:15-29 https://doi.org/10.1016/0169-5150(91)90013-B

Linn T, Maenhout B (2019) The impact of environmental uncertainty on the performance of the rice supply chain in the Ayeyarwaddy Region, Myanmar. Agric Food Econ 7:11 https://doi.org/10.1186/s40100-019-0128-6

Magalhães RS (2007) Habilidades sociais no mercado de leite. RAE-Rev Adm Empres 47:15-25

Martins PDC, Álvares JG, Barros GDC, Nogueira Netto V, Barroso M (2004) O futuro do cooperativismo de leite. Embrapa Gado de Leite, Juiz de Fora, MG

Mayen CD, Balagtas JV, Alexander CE (2010) Technology adoption and technical efficiency: organic and conventional dairy farms in the United States. Am J Agric Econ 92:181-195

Meeusen W, van Den Broeck J (1977) Efficiency estimation from Cobb-Douglas production functions with composed error. Int Econ Rev. 18:435 https://doi.org/10.2307/2525757

Morrison CJ (1985) Primal and dual capacity utilization: an application to productivity measurement in the U.S. automobile industry. J Bus Econ Stat 3:312 https://doi.org/10.2307/1391716 
Mosheim R, Lovell CK (2009) Scale economies and inefficiency of US dairy farms. Am J Agric Econ 91:777-794

Nderitu PC, Ndiritu SW (2018) Effects of mergers on processed milk market in Kenya. J Agribus Dev Emerg Econ 8:480-500 https://doi.org/10.1108/JADEE-04-2016-0021

Nguyen VK, Thi Hai Yen H, Van Khai T, To LH, Duc NT (2018) Key analysis of the dairy value chain in Vietnam: the case of Bavi. J Agribus Dev Emerg Econ 8:222-233 https://doi.org/10.1108/JADEE-06-2016-0041

Nightingale C, Dhuyvetter K, Mitchell R, Schukken Y (2008) Influence of variable milk quality premiums on observed milk quality. J Dairy Sci 91:1236-1244 https://doi.org/10.3168/jds.2007-0609

Noev N, Dries L, Swinnen JFM (2009) Institutional change, contracts, and quality in transition agriculture: evidence from the Bulgarian dairy sector. East Eur Econ 47:62-85 https://doi.org/10.2753/EEE0012-8775470404

OCB/Embrapa, 2015. Censo das Cooperativas do Leite, 2015 - síntese dos resultados.

OECD, FAO (2015) OECD-FAO Agricultural Outlook 2015, OECD-FAO Agricultural Outlook. OECD Publishing, Paris

Olsen NV, Elvekrok I, Nilsen ER (2012) Drivers of food SMEs network success: 101 tales from Norway. Trends Food Sci Technol 26:120-128 https://doi.org/10.1016/j.tifs.2012.01.008

Omondi I, Rao EJO, Karimov AA, Baltenweck I (2017) Processor linkages and farm household productivity: evidence from dairy hubs in East. PROCESSOR LINKAGES AND FARM HOUSEHOLD PRODUCTIVITY. Agribusiness, Africa https://doi.org/10.1 002/agr.21492

Porter PK, Scully GW (1987) Economic efficiency in cooperatives. J Law Econ 30:489-512

Revoredo-Giha C, Renwick A (2016) Market structure and coherence of international cooperation: the case of the dairy sector in Malawi. Agric Food Econ. 4:8 https://doi.org/10.1186/s40100-016-0052-y

Ruiz-Guerra I, Molina-Moreno V (2014) La intangibilidad de las cooperativas como ventaja competitiva. Coop. Desarro. 22:47-54

Schultz TW (1964) Transforming traditional agriculture, science \& its conceptual foundations. Yale University Press, New Haven

Shani D, Chalasani S (1992) Exploiting niches using relationship marketing. J Consum Mark. 9:33-42

Shaw DS, Shaw AC, Shaw SS, Leigh R (1999) The single European market and SMEs: a comparison of its effects in the food and clothing sectors in the UK and Portugal. Reg Stud. 33:51-62 https://doi.org/10.1080/00343409950118913

Singh S, Coelli T, Fleming E (2001) Performance of dairy plants in the cooperative and private sectors in India. Ann Public Coop Econ. 72:453-479

Skevas I, Emvalomatis G, Brümmer B (2018) Productivity growth measurement and decomposition under a dynamic inefficiency specification: the case of German dairy farms. Eur J Oper Res 271:250-261 https://doi.org/10.1016/j. ejor.2018.04.050

Soboh R, Lansink AO, Dijk GV (2012) Efficiency of cooperatives and investor owned firms revisited: efficiency of cooperatives and IOF. J Agric Econ 63:142-157 https://doi.org/10.1111/j.1477-9552.2011.00324.x

Soboh RAME, Lansink AO, Giesen G, van Dijk G (2009) Performance measurement of the agricultural marketing cooperatives: the gap between theory and practice. Rev Agric Econ. 31:446-469 https://doi.org/10.1111/j.1467-9353.2009.01448.x

Soboh RAME, Lansink AO, Van Dijk G (2014) Efficiency of European dairy processing firms. NJAS - Wagening J Life Sci. 70-71: 53-59 https://doi.org/10.1016/..njas.2014.05.003

Soboh RAMER, Oude Lansink A, van Dijk G (2011) Distinguishing dairy cooperatives from investor-owned firms in Europe using financial indicators. Agribusiness 27:34-46 https://doi.org/10.1002/agr.20246

Tanner MA, Wong WH (1987) The calculation of posterior distributions by data augmentation. J Am Stat Assoc 82:528-540 https://doi.org/10.2307/2289457

van den Broeck J, Koop G, Osiewalski J, Steel MFJ (1994) Stochastic frontier models: a Bayesian perspective. J Econom. 61: 273-303 https://doi.org/10.1016/0304-4076(94)90087-6

von Braun, J., Hotchkiss, D., Immink, M. (Eds.), 1989. Nontraditional export crops in Guatemala: effects on production, income, and nutrition, research report.

Wang H-J (2002) Heteroscedasticity and non-monotonic efficiency effects of a Stochastic Frontier Model, vol 19

Wilkinson J, Rocha R (2006) Agri-processing and developing countries

\section{Publisher's Note}

Springer Nature remains neutral with regard to jurisdictional claims in published maps and institutional affiliations.

\section{Submit your manuscript to a SpringerOpen ${ }^{\circ}$ journal and benefit from:}

- Convenient online submission

- Rigorous peer review

- Open access: articles freely available online

High visibility within the field

- Retaining the copyright to your article

Submit your next manuscript at $\boldsymbol{\nabla}$ springeropen.com 